\title{
PENINGKATAN KUALITAS PEMBELAJARAN PKn DI SEKOLAH DASAR MELALUI MODEL PENGAJARAN BERMAIN PERAN
}

\author{
Norman Syam
}

\begin{abstract}
This classroom action research is intended to improve instructional quality in the subject of Pancasila and Kewarganegaraan (PKn) at primary school. The main focus of this research is to discover if role play model can be implemented to improve the quality of PKn. The research, conducted at the fifth grade in Primary School 5, Municipality of Bengkulu, used observation, open interview, and field note techniques in collecting data to be analyzed qualitively. The findings show that role play model can improve the instructional quality of PKn in Primary School. Therefore it is recommended the roleplay model to be applied at 3rd through 4 th grades for more learning experiences.
\end{abstract}

Key words: instruction, Pancasila and Kewarganegaraan, role play model.

\section{Abstrak}

Penelitian tindakan ini bertujuan meningkatkan kualitas proses pembelajaran Pancasila dan Kewarganegaraan (PKn) melalui model bermain peran di SD kelas 5, Kotamadya Bengkulu. Masalah pokok penelitian ini adalah "Dapatkah kualitas pembelajaran PKn ditingkatkan dengan menggunakan model bermain peran?". Metode penelitian ini adalah peneltian tindakan kelas kolaboratif, dengan subyek penelitian guru kelas V (lima) SD kelas 5 Kotamadia Bengkulu. Teknik pengumpulan data melalui observasi, wawancara terbuka, dan catatan lapangan. Data diolah secara deskriptif kualitatif. Hasil penelitian model bermain peran dapat meningkatkan hasil pembelajaran PKn dan proses belajar dan membelajarkan lebih bermakna bagi siswa. Rekomendasi yang diajukan antara lain pembelajaran model bermain peran dapat diterapkan pada siswa SD mulai dari kelas 3 sampai kelas 6, dalam pengajaran bermain peran harus difokuskan pada pemberian pengalaman belajar siswa.

Kata-kata Kunci: pembelajaran, Pancasila dan Kewarganegaraan, model bermain peran.

\section{PENDAHULUAN}

Sistem Pendidikan Nasional Indonesia yang berakar pada kebudayaan bangsa Indonesia serta berdasarkan Pancasila dan UUD 1945, berfungsi mengembangkan kemampuan dan membentuk watak serta peradaban bangsa yang bermartabat dalam rangka mencerdaskan kehidupan bangsa. Berdasarkan UU No. 20 tahun 2003, Pendidikan Nasional bertujuan untuk berkembangnya potensi peserta didik agar menjadi manusia yang beriman dan bertaqwa kepada Tuhan Yang Maha Esa, berakhlak mulia, sehat, berilmu, cakap, kreatif, mandiri, dan menjadi warga negara yang demokratis serta bertanggung jawab. Di samping itu, Pendidikan Nasional juga harus menumbuhkan jiwa patriotik dan mempertebal rasa cinta tanah air. Untuk itu, dalam kurikulum pendidikan wajib memuat pendidikan Pancasila, pendidikan agama, pendidikan kewarganegaraan. Pendidikan Pancasila dan Kewarganegaraan (PKn) di sekolah dasar dimaksudkan untuk menanamkan rasa cinta tanah air, meningkatkan semangat kebangsaan, serta membentuk kepribadian bangsa yang sesuai dengan falsafah, pandangan hidup, ideologi, dan dasar negara yaitu Pancasila.

PKn adalah pendidikan tentang nilai-nilai yang sasarannya bukan semata-mata pengalihan pengetahuan melainkan lebih ditekankan pada pembentukan sikap. Dengan demikian, mata pelajaran ini meliputi ranah kognitif, afektif, dan psikomotor dengan menitikberatkan ranah afektif. Tugas untuk melaksanakan misi tersebut bukanlah hal yang mudah dan diperlukan suatu pembelajaran yang tepat agar misi yang diembannya dapat tercapai. Untuk menanamkan nilai-nilai yang dikehendaki ini tentu saja melalui proses pembelajaran yang benarbenar tepat bagi pembelajaran pendidikan nilai agar pembentukan kepribadian siswa dapat tercapai.

Dalam rangka mencapai tujuan bidang studi ini, para guru seharusnya telah menerapkan caracara pendidikan nilai pada kegiatan pengajaran di kelas. Namun pada kenyataannya, pembelajaran PKn di sekolah dasar belum menerapkan pembelajaran pendidikan nilai secara benar. Akibatnya pembelajaran 
nilai dan pembentukan kepribadian yang sesuai dengan nilai moral Pancasila hanya bersifat verbalisme saja, artinya anak didik hanya diberi pengetahuan tentang Pancasila bukan untuk diamalkan.

Berdasarkan pengamatan dan hasil diskusi dengan para guru di SD, guru belum menerapkan pembelajaran pendidikan nilai yang layak dalam pembelajaran PKn. Sementara itu, metode ceramah dan tanya jawab masih digunakan sangat dominan dalam menyampaikan bahan pelajaran, guru belum mendayagunakan model-model pembelajaran pendidikan nilai-moral. Padahal dalam kenyataannya banyak model pengajaran nilai moral yang dapat diterapkan oleh guru dalam menanamkan nilai moral Pancasila dalam rangka pembentukan kepribadian bangsa. Salah satu model pembelajaran yang bisa diterapkan dalam mata pelajaran PKn adalah model bermain peran.

Berdasarkan uraian diatas maka dapat dikemukakan permasalahannya: "Apakah kualitas pengajaran PKn dapat ditingkatkan dengan mengguna-kan model pembelajaran bermain peran?". Sedangkan yang menjadi tujuan penelitian ini adalah untuk (1) memperoleh gambaran mengenai cara guru dalam mengajarkan bidang studi PKn, (2) memberikan masukan bagi guru tentang pelaksanaan kegiatan mengajar bidang studi PKn dengan model pembelajaran bermain peran, (3) membantu guru agar lebih meningkatkan kualitas pembelajaran bidang studi PKn, dan (4) Membantu guru agar lebih mampu memanfaatkan model pengajaran nilai-moral pada pengajaran PKn.

Penelitian ini diharapkan memberikan manfaat positif bagi peningkatan kualitas pendidikan dan pembelajaran bidang studi PKn di SD. Adapaun manfaat yang dapat diberikan adalah (1) bagi guru, agar lebih mampu mengembangkan strategi belajar mengajar PKn serta terlaksananya misi pengajaran PKn, yaitu menanamkan nilai-moral Pancasila dan membentuk kepribadian siswa dapat tercapai; (2) bagi siswa, agar lebih bergairah dan lebih mudah mengikuti pelajaran $\mathrm{PKn}$; dan (3) bagi pendidikan secara makro, agar dapat membentuk generasi muda yang memiliki jiwa patriotik,cinta tanah air, memiliki semangat kebangsaan yang tinggi.

\section{KAJIAN PUSTAKA}

\section{Pendidikan Kewarganegaraan.}

Pendidikan Kewarganegaraan merupakan salah satu mata pelajaran yang terdapat dalam kurikulum sekolah. PKn berusaha membina perkembangan moral anak didik sesuai dengan nilai-nilai Pancasila agar dapat mencapai perkembangan secara optimal dan dapat mewujudkan dalam kehidupannya sehari-hari (Daryono, dkk., 1977: 1).

Mata pelajaran Pancasila dan Kewarganegaraan adalah mata pelajaran untuk mengembangkan moral serta meningkatkan mutu kehidupan dan martabat manusia Indonesia yang berkepribadian Indonesia sesuai dengan tujuan pendidikan nasional, sebagaimana yang di amanatkan dalam UU. RI No. 20 Tahun 2003, Tentang Sistem Pendidikan Nasional, bahwa Pendidikan Nasional bertujuan untuk berkembangnya potensi peserta didik agar menjadi manusia yang beriman dan bertakwa kepada Tuhan Yang Maha Esa, berakhlak mulia, sehat, berilmu, cakap, kreatif, mandiri, dan menjadi warga negara yang demokratis serta bertanggung jawab.

Untuk terwujudnya tujuan Pendidikan Nasional tersebut guru harus mampu dan siap untuk menanamkan nilai-nilai moral kepada diri siswa sebagai generasi penerus, agar memiliki kepribadian yang sesuai dengan tujuan pendidikan nasional dan berjiwa Pancasila.

\section{Model Bermain Peran}

Bermain peran merupakan salah satu model yang dapat di gunakan dalam pembelajaran yang berdimensi pribadi dan dimensi sosial, seperti yang di ungkapkan oleh Dahlan (1990 : 123). Model bermain peran adalah suatu model pembelajaran yang berakar pada dimensi pribadi dan dimensi sosial kependidikan. Dari sudut dimensi pribadi model ini berupaya membantu individu menemukan makna dari lingkungan sosial yang bermanfaat bagi dirinya.

Bila dilihat dari dimensi sosial, model ini memberikan kesempatan kepada siswa untuk bekerja sama dalam menganalisis situasi-situasi sosial terutama masalah-masalah hubungan antar pribadi siswa. Pemecahan masalah dilakukan secara demokrasi, dengan demikian model bermain peran mendorong siswa turut aktif dalam pemecahan masalah serta menyimak secara seksama bagaimana orang lain berbicara tentang masalah yang tengah dihadapi.

Bermain peran merupakan usaha untuk memecahkan masalah melalui peragaan tindakan, sehingga dapat mendukung suatu situasi belajar berdasarkan pengalaman. Di samping itu, bermain peran mengasumsikan bahwa proses psikologis yang tersembunyi berupa sikap, nilai-nilai, perasaanperasaan, dan sistem keyakinan, dapat diangkat ke taraf kesadaran melalui kombinasi pemeranan secara spontan. Model ini dalam aplikasinya pada pembelajaran $\mathrm{PKn}$ adalah bentuk permainan 
pendidikan yang dimanfaatkan untuk menjelaskan sikap-sikap, tingkah laku, dan nilai-nilai moral dalam kehidupan bermasyarakat dengan cara menghayati perasaan orang lain (membayangkan diri sendiri, seperti keadaan orang lain) dengan strategi pemecahan masalah.

\section{METODOLOGI PENELITIAN}

\section{Rancangan Penelitian}

Penelitian ini dilaksanakan di Sekolah Dasar Negeri 5 Padang Harapan, Kota Bengkulu, dengan pertimbangan SD ini adalah mitra kerja PGSD FKIP UNIB dalam melaksanakan program-program PGSD (PPSD dan PPL). Penelitian ini dilaksanakan pada kelas 5, dengan menggunakan Penelitian Tindakan Kelas (PTK) dengan model Siklus. PTK ini diawali dengan mendiskusikan masalah-masalah yang dialami guru dalam pengelolaan PBM dan dirasakan perlu segera diatasi.

Tindakan dilakukan siklus demi siklus sampai teratasi kesulitan yang ditemukan. Pelaksanaan penelitian tindakan kelas dilakukan dengan urutan sebagai berikut (1) perencanaan, (2) pelaksanaan tindakan, (3) hasil, (4) refleksi, dan (5) revisi perencanaan.

\section{Kegiatan dan Pengamatan}

1. Persiapan

Sebelum melakukan tindakan, Tim secara keseluruhan masuk kekelas yang akan dilaksanakan tindakan. Hal ini dilakukan untuk memperkenalkan seluruh Tim pada siswa, dengan tujuan agar siswa tidak asing bila dilaksanakan tindakan, siswa tidak canggung dengan kehadiran Tim di kelas. Mengadakan dialog dengan siswa dalam rangka menjajaki sikap siswa terhadap pembelajaran PKn. Uji coba sekaligus memberi contoh pada guru dalam melaksanakan bermain peran pada kelas yang sebenarnya.

2. Kegiatan Tindakan

Pelaksanaan model ini melalui tahapan-tahapan sebagai berikut.

a. Kegiatan guru

Pada awal pembelajaran guru mengadakan apersepsi, menginformasikan materi pelajaran dan kegiatan pembelajaran bermain peran dengan beberapa tahapan: (1) memotivasi kelompok, (2) memilih pemeran; menganalisis peran, memilih dan menetapkan peran, (3) menyiapkan pengamat, (4) menyiapkan tahapan-tahapan peran, (5) siswa melaksanakan peran, (6) diskusi dan evaluas, dan (7) guru dan siswa menyimpulkan materi peran yang sudah dilaksanakan.

b. Kegiatan siswa
Siswa menerima informasi tentang materi dari guru, kemudian siswa melaksanakan informasi dari guru dengan tahapan: (1) memilih masalah yang ditawarkan guru, (2) memilih pemeran yang akan diperankan, (3) menyiapkan pengamat, (4) menyiapkan tahap-tahap peran, (5) pemeranan (melak-sanakan bermain peran), (6) diskusi dan evaluasi, dan (7) menyimpulkan peran yang sudah dilaksanakan.

\section{Refleksi dan Pengembangan}

Refleksi dilakukan pada setiap akhir dari pelaksanaan tindakan. Setiap selesai melakukan tindakan tim, guru, dan kepala sekolah berkumpul membahas tindakan yang telah dilakukan, dan mengevaluasi hasil yang telah dicapai bersama-sama. Dari evaluasi dan diskusi ini, dicari kelemahan dan kekuatan dalam pelaksanaan. Kelemahannya dicarikan solusinya agar lebih meningkatkan kualitas tindakan berikut, sedangkan kebaikan/keuntungannya makin dipertahankan dan dipertajam.

\section{Revisi Rancangan}

Penyempurnaan rancangan dilakukan dengan mempertimbangkan dan melihat hasil diskusi dan evaluasi tim, guru dan kepala sekolah. Kemudian di buat rencana baru dengan perbaikan pada hal-hal yang memiliki kelemahan.

\section{HASIL DAN PEMBAHASAN}

\section{Siklus Pertama}

Berdasarkan pengamatan/pemantauan ditemukan: (1) kegiatan pengajaran masih di dominasi oleh guru, (2) keaktifan siswa belum nampak secara spontan, (3) diskusi antar siswa belum terjadi, (4) pengungkapan pengalaman siswa dan pengungkapan nilai-nilai moral siswa belum tercapai, (5) guru nampak kaku dalam melaksanakan model bermain peran, (6) guru belum melibatkan lingkungan dan dunia siswa pada saat mengidentifikasi masalah, dan (7) siswa masih kaku karena belum terbiasa.

\section{Siklus Kedua}

Dari pelaksanaan siklus kedua ditemukan hasil: (1) pada saat penentuan masalah, siswa belum dilibatkan, (2) pada saat analisis pemeran, guru menganalisisnya sendiri tanpa melibatkan siswa, dan (3) siswa kurang diberikan semangat/dorongan untuk mengekspresikan perasaan dan gagasannya secara bebas.

\section{Siklus Ketiga}

Dari hasil pengamatan dan pemantauan peran pada siklus ketiga diperoleh: (1) guru/praktisi merasa senang memanfaatkan model bermain peran, siswa lebih bergairah dalam proses pembelajaran, (2) 
keterlibatan siswa dalam proses belajar meningkat, (3) pemberian pengalaman belajar pada siswa dapat tercapai, (4) pengajaran lebih bermakna bagi siswa, dan (5) siswa yang pemalu, mulai berani dalam mengemukakan pendapat dan mengekspresikan dirinya pada saat proses belajar membelajarkan.

\section{Dampak Instruksional}

Pemanfaatan model bermain peran pada pembelajaran PKn menunjukkan adanya peningkatan kualitas pembelajaran di sekolah. Peningkatan ini tidak hanya terbatas pada pemahaman siswa pada materi pelajaran melainkan juga pada aspek nilai-nilai, sikap dan perasaan siswa yang diungkapkan pada saat PBM, melalui diskusi, pemeranan dan pada pengungkapan pengalaman-pengalaman siswa.

Pada permulaan pembelajaran PKn dengan bermain peran, siswa tidak berani mengemukakan pendapat, gagasan, menentukan sikap. Akan tetapi setelah diadakan melalui siklus-siklus, siswa telah berani menentukan sikap dalam memilih topik yang akan dimainkan, demikian pula pada saat pemilihan peran. Siswa telah mampu mengekspresikan sikap dan perasaannya dalam pemeranan yang dimainkan.

Siswa telah dapat melakukan diskusi tentang masalah perilaku, sikap yang dia anggap baik dan benar tanpa merasa canggung dan malu atau takut. Disamping itu melalui diskusi tukar pengalaman belajar yang mereka rasakan, siswa mampu mengembangkan pemecahan masalah pribadi dan masalah antar pribadi melalui proses pemeranan dan diskusi. Dampak instruksional yang lain didapat oleh siswa adalah kemampuan mengembangkan sikap empati terhadap apa yang dialami oleh orang lain melalui pengamatan pemeranan dan diskusi dalam kelompok. Dengan demikian, guru telah membina sikap toleran dan penghargaan terhadap orang lain, serta membiasakan siswa untuk mampu mengendalikan egonya.

\section{Dampak Pengiring}

Efek pengiring model membelajarkan dengan bermain peran ini diketahui dari pengakuan guru praktisi, siswa yang melakukan kegiatan, serta hasil pengamatan serta pengakuan kepala sekolah dan dosen PGSD sebagai peneliti adalah dengan bermain peran siswa dapat mengapresiasikan pendapat orang lain dan mampu mengekspresikan pendapatnya sendiri. Siswa juga memperoleh informasi tentang masalah-masalah sosial dan nilai-nilai. Kemampuan ini membuat mereka dapat membangun kerja sama dengan kelompok dan bersama-sama pula memecahkan masalah-masalah sosial di lingkungan dan dunianya secara demokrasi serta dapat melaksanakan musyawarah dalam kelompoknya.

\section{Faktor Pendukung dan Penghambat}

\section{Faktor Pendukung}

1. Adanya dukungan kepala sekolah, baik dukungan administrasi maupun dukungan moril.

2. Guru-guru yang dilibatkan oleh kepala sekolah adalah guru-guru yang memiliki kreativitas yang baik, memiliki semangat tinggi dan keinginan untuk meningkatkan kemampuan profesionalnya.

3. Tingginya perhatian guru terhadap pelaksanaan model bermain peran, serta memiliki rasa ingin tahu yang tinggi terhadap pelaksanaan Penelitian Tindakan Kelas.

4. Adanya kerja sama yang baik antara kepala sekolah, guru, siswa dan dosen PGSD.

Faktor Penghambat

1. Pola pembelajaran guru yang tidak sejalan dalam pengelolaan proses belajar membelajarkan yang menggunakan model bermain peran

2. Jumlah murid perkelas terlalu banyak, sehingga kesulitan guru mengelola kelas pada saat berlangsungnya pemeranan dan diskusi.

3. Latar belakang pengetahuan dan kemampuan guru beragam terutama dalam mengembangkan strategi belajar membelajarkan pendidikan nilai dan pemanfaatan pendekatan dalam pembelajaran PKn.

4. Kemampuan anak mengungkapidedan gagasannya dalam bahasa Indonesia kurang, sehingga membuat anak sulit dalam menuangkan ide secara jelas. Di samping itu, latar belakang budaya dan kebiasaan belajar anak selama ini menjadi penghambat dalam pelaksanaan model bermain peran.

\section{PENUTUP}

\section{Kesimpulan}

Berdasarkan hasil penelitian dan pembahasan yang telah dikemukakan di atas, dapat disimpulkan sebagai berikut.

Pertama, model bermain peran dapat meningkatkan proses belajar mengajar PKn di Sekolah Dasar. Kedua, penggunaan model bermain peran proses belajar mengajar lebih bermakna bagi siswa. Ketiga, model bermain peran dapat diterapkan pada siswa Sekolah Dasar mulai dari kelas tiga sampai dengan kelas enam. Keempat, dalam pengajaran bermain peran harus difokuskan pada pemberian pengalaman belajar siswa.

\section{Saran}

Didasarkan simpulan dari hasil penelitian di atas disarankan sebagai berikut.

Pertama, dalam rangka meningkatkan mutu pembelajaran maka pada guru senantiasa 
berusaha, menggali dan menciptakan model-model pembelajaran yang inovatif pada mata pelajaran tertentu. Kedua, model bermain peran telah terbukti dapat meningkatkan pembelajaran PKn, maka sudah selayaknya diterapkan pada setiap kali pembelajaran. Ketiga, untuk mendukung terlaksananya model bermain peran perlu pengadaan sarana prasarana yang memadai. Keempat, agar terlaksana model bermain peran perlu dukungan dari semua pihak, kepala sekolah, guru, dan orang tua murid.

\section{DAFTAR PUSTAKA}

Dahlan, M.D. (1984.) Beberapa alternatif interaksi belajar mengajar, model-model mengajar. Bandung: Diponogoro.

Daryono, M. (1997). Pengantar Pendidikan Pancasila dan Kewarganegaraan. Jakarta: Rineka Cipta.

Djahiri, A. K., et al. (1990). Pengembangan program dan kegiatan belajar mengajar pendidikan Pancasila.
Bandung: FPIPS-IKIP Bandung.

Djahiri, A. K., et. al. (1996). Dasar dan konsep pendidikan moral. Jakarta: Depdikbud Dirjen Dikti P2TA

Depdikbud. (1995). Pendidikan Pancasila dan Kewarganegaraan Sekolah Dasar Kelas 5. Jakarta: Dirjen Pendidikan Dasar dan Menengah.

Muhajir, N. (1997). Pedoman pelaksanaan penelitian tindakan kelas (PTK). Yogyakarta: Depdikbud Proyek Pendidikan Tenaga Akademik BP3GSD UP3SD UKMP-SD

Wahab, A. A. (1995). Pendidikan Pancasila dan Kewarganegaraan (PKn). Bandung: Depdikbud Dirjen Dikti PP3SD

\section{KETERANGAN PENULIS}

Norman Syam, saat ini bertugas sebagai dosen dan sekretaris jurusan Prodi PAUD FKIP Universitas Negeri Bengkulu. 